\title{
Association of intravenous albumin with alkaline phosphatase activity
}

\author{
B. M. RIGG AND CAMERON W. BAIRD \\ From the Department of Biochemistry, Royal Melbourne Hospital
}

SYNOPSIS After albumin transfusion levels of alkaline phosphatase are raised. These levels were studied in selected groups of patients and in albumin prepared for transfusion using a heat sensitivity test, and by this means the significance of raised levels of alkaline phosphatase may be interpreted correctly.

Estimations of serum 'alkaline phosphatase' are frequently made in the diagnosis of liver and bone disease, the term 'alkaline phosphatase' being used to refer to the activity of the enzyme. Recently, certain patients not suffering from either of these conditions were noted to have markedly raised levels of serum alkaline phosphatase (group 3a). In considering the reasons for these high values, we were reminded of the paper by Neale, Clubb, and Posen (1963) who reported elevated levels of alkaline phosphatase following albumin transfusion. It was decided therefore to review the patients noted above with elevated levels of alkaline phosphatase. All of these patients had received a variable quantity of albumin before the estimation of the alkaline phosphatase levels. Consequently the relationship of albumin to this enzyme was investigated, to elucidate possible confusion produced by this artificial elevation of alkaline phosphatase.

METHOD

ENZYME GROUPS Estimations of enzyme activity were grouped as follows:

Group 1 Alkaline phosphatase activity in patients with obstructive jaundice.

Group 2 Alkaline phosphatase activity of Commonwealth Serum Laboratory ${ }^{1}$ (C.S.L.) albumin.

Group 3 Alkaline phosphatase activity of patients who had received intravenous albumin.

TECHNIQUE Using auto-analyser equipment the alkaline phosphatase activity of the serum was estimated at $37^{\circ} \mathrm{C}$. by the Powell and Smith modification of the Kind and King technique (Powell and Smith, 1954). The enzyme activity was then redetermined by the same method after heat inactivation at $56^{\circ} \mathrm{C}$. for 45 minutes, as described by Neale et al. (1963).

${ }^{1}$ Commonwealth Serum Laboratories, 45 Poplar Road, Parkville, Melbourne, Victoria.

Received for publication 23 December 1964.

\section{RESULTS}

Results are expressed in King Armstrong units per $100 \mathrm{ml}$. of serum or albumin respectively, and are set out in Tables I, II, III, and IV.

The alkaline phosphatase activity at one week in case 2 was lower than one might expect. However, after thorough review no clinical or technical reason for this reading could be found.

TABLE I

PATIENTS WITH OBSTRUCTIVE JAUNDICE

Case No. Alkaline Phosphatase Activity

\begin{tabular}{ccc} 
Case No. & \multicolumn{2}{c}{ Alkaline Phosphatase Activity } \\
\cline { 2 - 3 } & Pre.heat & Post-heat \\
\hline 1 & 100 & $4 \cdot 2$ \\
2 & 48 & $5 \cdot 9$ \\
3 & 200 & 12 \\
4 & 46 & 2
\end{tabular}

TABLE II

ALKALINE PHOSPHATASE ACTIVITY OF C.S.L. ALBUMIN

\begin{tabular}{lcc}
$\begin{array}{l}\text { Batch } \\
\text { Number }\end{array}$ & \multicolumn{2}{c}{ Alkaline Phosphatase Activity } \\
\cline { 2 - 3 } & Pre-heat & Post-heat \\
\hline 301 & 1,450 & 1,450 \\
302 & 48 & 48 \\
302 & 50 & 46 \\
302 & 47 & 45 \\
302 & 43 & 43 \\
303 & 18 & 14 \\
305 & 42 & 41
\end{tabular}

TABLE III

PATIENTS RECEIVING ALBUMIN OVER AN UNLIMITED PERIOD

\begin{tabular}{ccc} 
Case No. & \multicolumn{2}{c}{ Alkaline Phosphatase Activity } \\
\cline { 2 - 3 } & Pre-heat & Post-heat \\
\hline 1 & 86 & 66 \\
2 & 960 & 950
\end{tabular}


TABLE IV

PATIENTS RECEIVING 1 LITRE OF ALBUMIN INTRAVENOUSLY OVER EIGHT HOURS

Case Alkaline Phosphatase Activity

No.

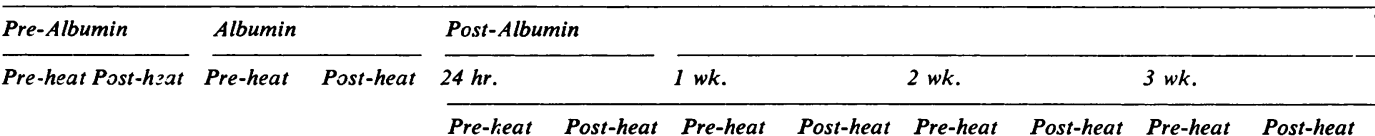

\begin{tabular}{lllll}
\hline 1 & 18 & 0 & 48 & 4 \\
2 & 18 & 3 & 46 & 4 \\
3 & 13 & 0 & 30 & 27
\end{tabular}

$\begin{array}{lll}46 & 38 & 14 \\ 45 & 27 & 23 \\ 27 & 18 & 10\end{array}$

14
23
10

\section{DISCUSSION}

Alkaline phosphatase is a phosphomonoesterase with maximum activity at $p \mathrm{H} \mathrm{9.8,} \mathrm{and} \mathrm{has} \mathrm{been} \mathrm{iso-}$ lated from liver, bone, kidney, intestine, and placenta Wilkinson (1962). Placental albumin is used as a supplement in the preparation of C.S.L. albumin (Hinton, 1964).

By various techniques-immunological, electrophoretic, and chromatographic - the alkaline phosphatase from these various organs has been differentiated, but in general these techniques are complex (Abderhalden, 1961). In contrast the heat sensitivity test used in this investigation is both simple and quick.

It has been shown that endogenous alkaline phosphatase is almost entirely heat sensitive; C.S.L. albumin contains a variable and sometimes large amount of heat-stable alkaline phosphatase; intravenous transfusion of C.S.L. albumin raises the serum alkaline phosphatase to a variable extent, so that it is heat stable, and the degree and duration of the raised level is directly related to the alkaline phosphatase contents of the albumin.

The value of distinguishing exogenous from endogenous alkaline phosphatase is particularly signifi- cant in the differential diagnosis of patients with jaundice who may have received albumin. Raised? levels of heat-sensitive alkaline phosphatase are seen $\overline{0}$ in obstructive jaundice, whereas increased levels of + heat-stable alkaline phosphatase suggest that infused $\stackrel{\vec{t}}{\vec{t}}$ albumin may be the source of alkaline phosphatase.

\section{CONCLUSION}

Different batches of C.S.L. albumin contain variable $\vec{\oplus}$ amounts of heat-stable alkaline phosphatase, which after intravenous transfusion raise the serum alkaline phosphatase level. In assessing the significanceo of elevated levels of alkaline phosphatase activity it is therefore necessary to consider the possibility of previous albumin transfusion. Such elevated levels $\frac{0}{\circ}$ of alkaline phosphatase may be diagnosed by the heat inactivation test described above.

\section{REFERENCES}

Abderhalden, R. (1961). Clinical Enzymology. van Nostrand, Princeton, New Jersey.

Hinton, M. R. (1964). Personal communication.

Neale, F. C., Clubb, J. S., and Posen, S. (1963). Med. J. Aust., 2, 684.

Powell, M. E. A., and Smith, M. J. H. (1954). J. clin. Path., 7, 245.

Wilkinson, J. H. (1962). An Introduction to Diagnostic Enzymology. Arnold, London. 